\title{
Relation of lineaments and volcano-stratigraphy of tertiary volcanic rocks in Kulon Progo Mountains Area, Yogyakarta-Indonesia
}

\author{
Asmoro Widagdo ${ }^{1, *}$, Subagyo Pramumjoyo ${ }^{1}$, and Agung Harijoko ${ }^{1}$ \\ ${ }^{1}$ Department Geological Engineering, Faculty of Engineering, Universitas Gadjah Mada, Indonesia
}

\begin{abstract}
The structural lineaments developed in the Kulon Progo Mountains, which is mainly composed of Tertiary volcanic rocks. The direction and distribution of these lineaments density differs from one area to another. This research was conducted to reveal the geological factor of controlling the variation of existing lineaments density. Lineaments delineation is done on the whole area on the satellite image of Kulon Progo Mountain area. From the lineaments map is then made a lineaments density variation map. Lineaments density variation map that are overlaid by volcanic rock distribution, based on the results of field studies, will result in a relationship between the geological structure density and the existing rock types and facies of volcanic rocks. The result of alignments density analysis shows high density values 3-6 $\mathrm{km} / \mathrm{km}^{2}$ especially located at proximal volcanic rock facies. Low density values of $1-3 \mathrm{~km} / \mathrm{km}^{2}$ are mainly located in medial and distal volcanic rock facies.
\end{abstract}

\section{Introduction}

The research area is located in Kulon Progo Mountain, Special Province of Yogyakarta-Indonesia. In this area, there is a phenomenon of geological structure that develops on the body of Tertiary age volcanic rocks. Research on volcanic geology as well as geological structure in this area has been done by many researchers such as by [1-14]. Normal fault is very common and shows a radial pattern around the body of Oligo-Miocene age volcano that still looks quite ideal [2]. This can be seen also in the Geological Map of Yogyakarta Sheet, according to [3-5] studies volcanic facies in the southern part of Kulon Progo Mountain.

Tectonic effects in controlling formation of Kulon Progo Mountain [6]. [8] concludes that the unique morphological expression of the Kulon Progo Mountains are caused by the general trend of tectonics that has occurred in Java since Eocene. [15] and [16] interpreted north northeast-south southwest (NNE-SSW) directional alignment as ProgoMuria alignment. [17], cited the existence of a transform fracture that accommodates East Java's micro-continent shift to be the forerunner of the Progo-Muria Fault. [10] mentioned that the geological structure found in the Kulon Progo Mountains in the form of a strike slip fault with a longitudinal direction in the southeast-northwest (SE-NW) also found normal faults in the east-west (E-W) direction.
[18] suggests that the unique morphological expression of Kulon Progo Mountains is due to the general trend of tectonics working on Java since Eocene age. [11] mentions the geological structure that controls distribution of rocks in Kulon Progo Mountains in the form of normal faults, thrust faults and strike-slip faults. [12] mentions geological structures such as joint, fold and fault can be found in Kulon Progo Mountains, formed by northwest-southeast (NW-SE) trending. [13] mentions the presence of shear joint, tensional joint, normal fault, thrust fault, strike-slip fault and fold in Kulon Progo Mountains. [14] mentions that the geologic structure developed in the research area is produced by compressional tectonic and extensional tectonic phases.

Research that specifically discusses the geological structure and its relation to the facies of volcanic rock in the study area has not been deeply conducted. For this reason, this research is conducted to find out correlation of direction and lineaments density of geological structure resulting from image interpretation which can be a joint or a fault with facies of volcanic rock in Kulon Progo Mountains.

\section{Methods}

The research method used is through image delineation and field work. Image delineation is performed to illustrate the distribution of three existing Tertiary age volcanoes namely Mount Gajah, Ijo and Menoreh. Delineation of geological structural alignments are also performed on the image of the

\footnotetext{
* Corresponding author: asmoro_widagdo@yahoo.com
} 
entire Kulon Progo Mountain region including Gajah, Ijo and Menoreh volcano. To the map of geological structure lineaments then made lineaments density variation map every area of one square kilometer $\left(\mathrm{km} / \mathrm{km}^{2}\right)$.

Field work was carried out to illustrate the distribution of lithology variations that resulted in a map of the distribution of central, proximal, medial and distal facies on Gajah, Ijo and Menoreh volcano. Field work was also conducted to verify the results of the interpretation of the volcano's body distribution of Gajah, Ijo and Menoreh. Fieldwork also ensures the types of geological structures such as joints, faults and folds in the field.

From the lineaments map of the geological structures is made a bar chart of the number of lineaments and rose diagrams of each lineaments on each body of the Tertiary volcanic and the existing sedimentary rock formations. Older rocks will generally record more and more varied geological structures compared to younger rocks. Lineaments density variation map then overlay on map of facies volcano distribution of Gajah, Ijo and Menoreh. From this overlay can be seen relationship level of lineaments density with facies of volcanic rocks.

\section{Results and discussion}

\subsection{Volcano-Stratigraphy of Kulon Progo Mountains}

Kulon Progo Mountains are mainly composed of Tertiary volcanoes. The Old Andesite Formation [1] is the name used to cover all volcanic rocks in the Kulon Progo Mountains. Further divisions were made by [3] and [4], by dividing Kulon Progo Mountains into 3 parts namely Kebobutak Formation, Andesite Intrusion and Dacite Intrusion. Through the interpretation of the image in this study is known the distribution of Gajah, Ijo and Menoreh volcanic body, and the order of its formation.

In line with [19], the result of volcanic body delineation shows that Kulon Progo Mountains are composed of three Tertiary volcano bodies. In the southern part there is a circular pattern that is still intact from Ijo volcano. This intact circular pattern covers the body of Gajah volcano in the middle of Kulon Progo Mountain. With this crosscutting relationship, it is certain that volcano Gajah is older than Ijo volcano.

In the north, there is a half-ridged pattern of Menoreh volcanoes. This volcano has collapsed and now only half of it. The rest of this volcano opens to the north. The foot of this volcano is located above the body of Gajah volcano at the northern part. Image analysis, added Jonggrangan Formation rocks, shows that Mount Menoreh is overlying on this formation as well. Thus Menoreh volcano is younger than Gajah volcano and Jonggrangan/Sentolo Formations.

Menoreh volcano in the north has no direct connection with Mount Ijo in the south. Both volcano is younger than Mount Gajah. The age-sequence relationship between them can be determined by looking at the spread of the Jonggrangan Formation. In the south, the Jonggrangan Formation is above the body of Ijo volcano, while in the north the Jonggrangan Formation is under Menoreh volcano.
Thus the relative age of Ijo volcano is older than Menoreh volcano.

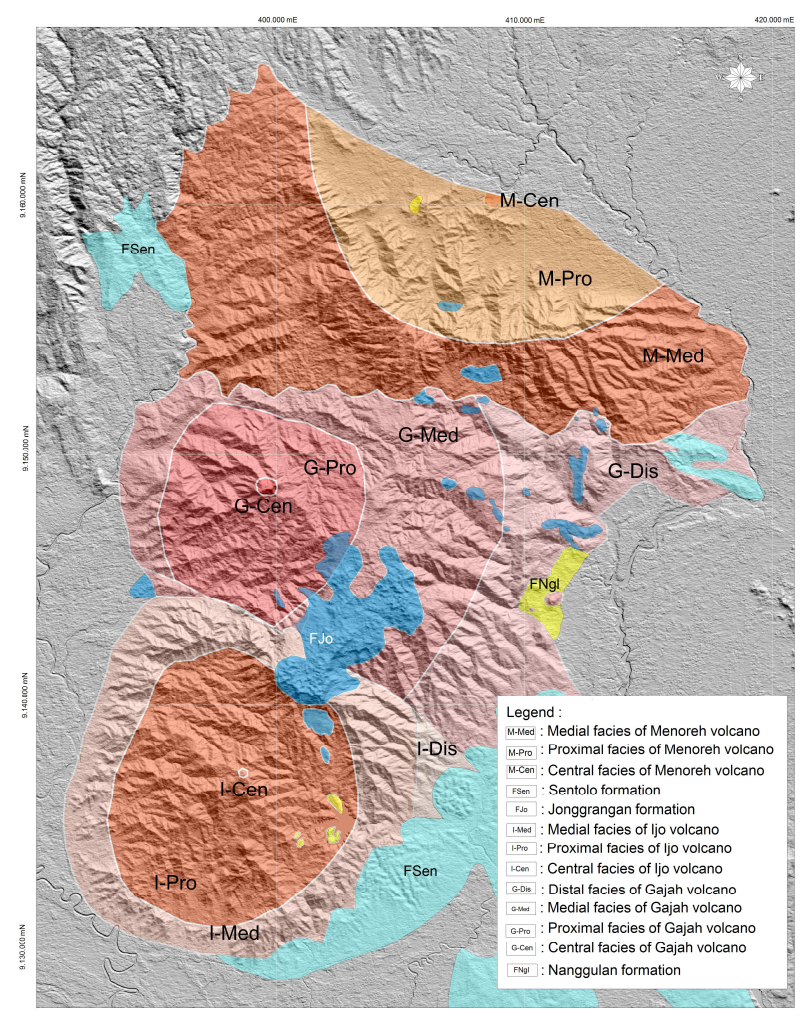

Fig. 1. Volcanic rock facies distribution of three Tertiary volcanics.

Observation of maps and imagery shows that the distribution of rocks of Mount Gajah in the middle of Kulon Progo Mountain is covered by erupted rocks of Mount Ijo. Mount Ijo more shows a circular pattern that is still intact, while Mount Gajah no longer shows this structure (Figure 1). This happens because Mount Gajah is closed by the presence of Ijo Mountain rocks. This cross-cutting relationship shows that Mount Gajah comes first and then Mount Ijo comes to close some parts of Mount Gajah (Figure 1). Almost the entire body of Mount Gajah which includes the medial and distal facies on the south side has been collapsed and covered by the material of Ijo volcano.

The determination of absolute age has been done by [20], Setijadji, 2005 in [19] and also by [21]. [20], mentions the age of Gajah volcano is 25.4-29.6 Million years. The age of Mount Ijo rock is $17.0+2.0$ to $16.0+2.2$ Million years. While Menoreh volcano according to Setijadji, 2005 in [19] and according to [21], is $11.4+0.7$ and $12.4+0.7$ million years or Upper Miocene.

[22], argued that the distribution of volcanic facies was developed by Vessel and Davies (1981) and [23] into four groups, namely Central/Vent Facies, Proximal Facies, Medial Facies, and Distal Facies. In accordance with the constraints of the volcano facies, ie a number of lithology features (physics and chemistry) of volcanic rocks at a particular location, each of these volcanic facies can be identified based on remote sensing and geomorphological data; stratigraphic volcanic rocks; physical volcanology; geological structure; as well as petrology-geochemistry. 


\subsection{Lineaments interpretation}

Lineament according to [24] is a phenomenon on the surface of the earth that exhibits the characteristics of a linear or curvilinear appearance associated with a fault or a weak zone. The straightness of the flow pattern is a common geomorphological expression of lineament. The different types of rocks also allow to give contrasting appearance to remote sensing imagery observations.

In Figure 2, depicted the results of the structural alignments of the structure of each volcanic body as well as the limestone formation of Sentolo and Jonggrangan. In this figure, there are 1,289 structural alignments. These lineaments come from 4 groups of rocks namely Mount Gajah, Mount Ijo, Sentolo-Jonggrangan Formation and Mount Menoreh. From this straightness data are made 3 diagrams. The rose diagram illustrates the percentage of lineaments in each rock group on the left side of Figure 2. The bar chart of the alignment ratio of all the units of rock is shown in Figure 3. The rosette diagram comparison of the percentage of lineaments of each rock group is presented in Figure 4.

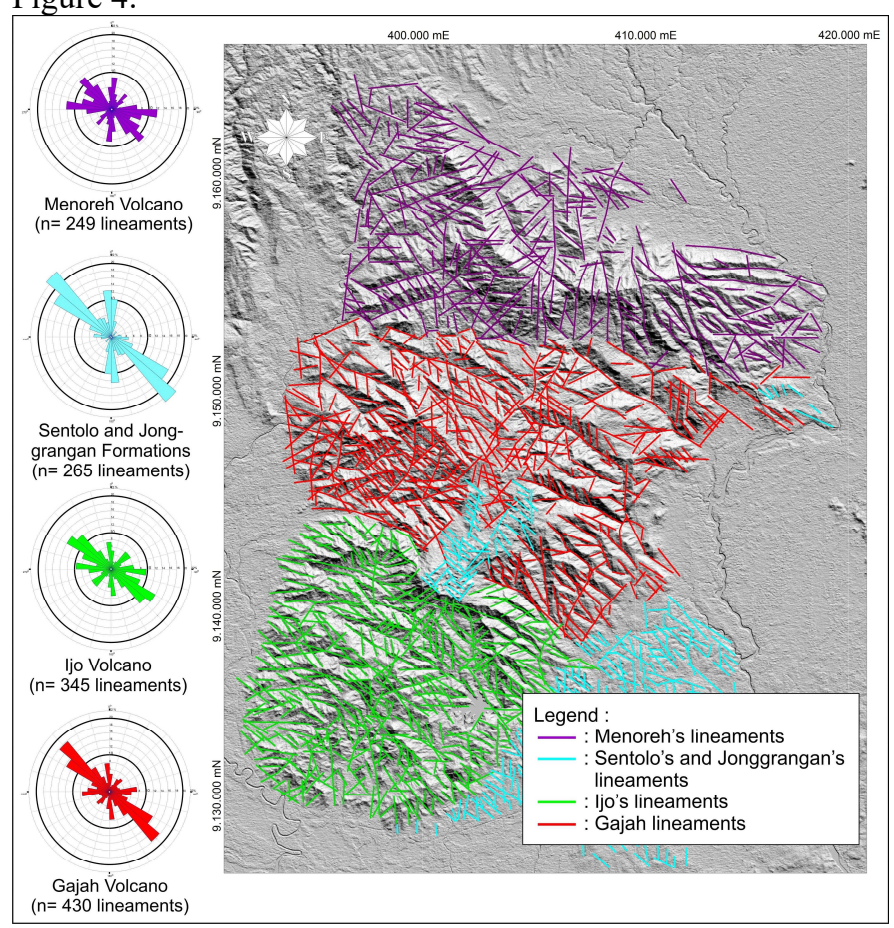

Fig. 2. Interpretation of structural lineaments of each volcanoes body and sedimentary rocks in the Kulon Progo Mountains.

Mount Gajah as the oldest volcanic rock group in the Kulon Progo Mountains shows the highest lineaments of 430 pieces or $33.35 \%$ of the entire existing alignments. The number of lineaments is the highest compared to the other rock groups in the Kulon Progo Mountain (Figure 3). As the oldest volcanic rocks, some of the structures formed on this volcano's body are also records of structures throughout the volcano's body to the youngest (Menoreh volcano) and the sedimentary rock group thereafter. The results of the drawing of the rosette diagram in Figure 4.7 resulted in a $39.5 \%$ northwest-southeast (NW-SE) general direction, west-east (EW) of $12.5 \%$, north-south (NS) of $12.5 \%$ and slightly $(10 \%)$ northeast-southwest direction (NE-SW). The percentage of lineaments is strongly dominated by northwest-southeast directed lineaments (NW-SE) of $39 \%$.
The percentage of lineaments in this direction, in the Kulon Progo Mountains is the highest percentage of lineaments after the same lineaments direction in the Jonggrangan and Sentolo Formation of limestone groups (Figure 4).

Mount Ijo as a second volcanic rock is present in Kulon Progo Mountain, indicating the presence of 345 majors or as many as $26.80 \%$ of the entire lineaments in the study area. In the depiction of the rose diagram of the straightness (Fig. 2) gives a $31.5 \%$ northwest-southeast direction (NW-SE), $15.5 \%$ east-west (EW), northeast-southwest (NE-SW) as much as $14 \%$, and a small number of north-south straightness (NS) as much as $12.5 \%$. The percentage of lineamentss direction indicates the dominant value in the northwest-southeast oriented straightness (NW-SE). The (NW-SE) on the body of Mount Ijo, is the third straightness after alignment with the same direction on the SentoloJonggrangan Formations and the Gajah volcanic rock group (Figure 4). As a rock formed after Mount Gajah, this volcano only records the structures that are formed thereafter, so the number of structures are less than the Gajah volcano, but still more than the other younger rocks (Figure 3).

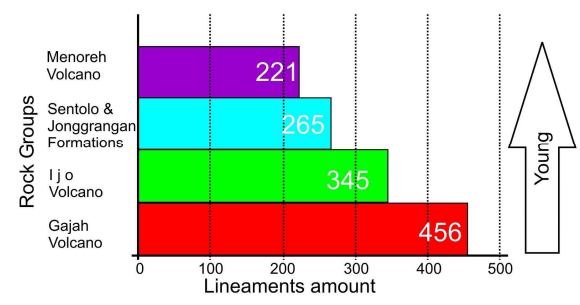

Fig. 3. Bar chart of the number of lineaments in each rock group.

In Sentolo and Jonggrangan Formation, indicating the presence of lineaments of 265 units or as much as $20.56 \%$ of the total lineaments. In the rose diagram of the lineaments, (Figure 2) gives an overview of the general direction of northwest-southeast (NW-SE) as much as $45 \%$; north-south (N-S) of $22.5 \%$; and a small number of eastwest $(\mathrm{E}-\mathrm{W})$ of $6.5 \%$. The percentage of lineaments directions shows the dominant value in the northwestsoutheast (NW-SE) direction. As rock formations that formed before Mount Menoreh, these formation record structures that also happen after Menoreh. The number of lineaments in this rock group is less than all older rocks, but still more than the younger rocks (Figure 3). In Figure 4, it appears that the northwest-southeast and north-south alignment is the dominant lineaments over the straightness with the same direction in the other rock groups in the Kulon Progo Mountains.

Menoreh volcano as the youngest volcanic rock present in Kulon Progo Mountains, shows the presence of lineaments of 249 pieces or as much as $19.32 \%$ of the overall lineaments. The rose diagram of the lineament, gives an overview of the general direction of northwest-southeast (NW-SE) as much as $30 \%$, west-east (E-W) as much as 26 $\%$, and north-south $(\mathrm{N}-\mathrm{S})$ as much as $14 \%$. In general, the percentage of lineament directions shows a value that is not much different. As rocks formed after Mount Gajah, Mount Ijo, and Sentolo-Jonggrangan Formation, Menoreh volcano only records the most recently formed structures, resulting in the least amount of structures compared to other older rocks. In Figure 4, it appears that the east-west (E-W) 
alignment recorded on the Menoreh Mountain group is the dominant alignments, compared to lineaments in the same direction in other older rock groups. This indicates that the lineaments of west-east direction (E-W) occurs after the formation of Menoreh volcano rock group. The east-west direction $(\mathrm{E}-\mathrm{W})$ directed at the older rocks is a young lineaments.

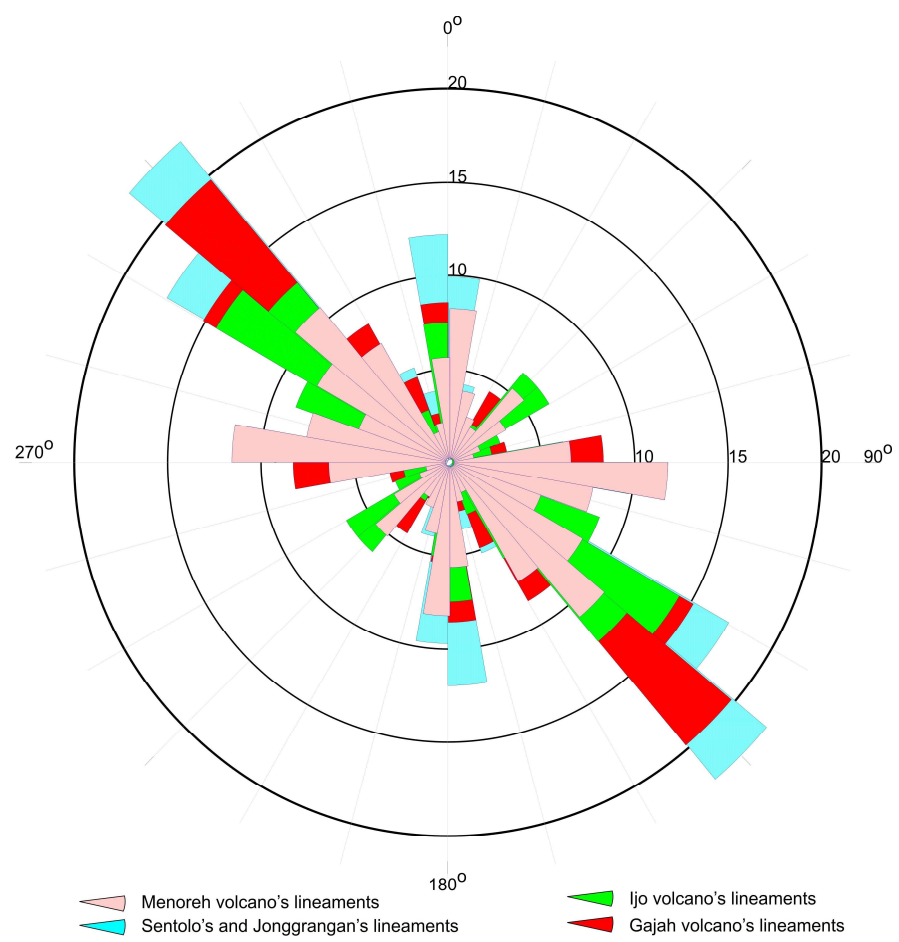

Fig. 4. Rose charts of the lineaments percentage in each volcanic body and sedimentary formation.

Based on the analysis of rose diagrams on the structure of the oldest to the youngest rocks, it shows that the eastwest trending structure (E-W) is the youngest structure in the Kulon Progo Mountains. This directional structure also concerns other older rocks or is recorded at all rock ages. The northwest-southeast trending (NW-SE) structure appears on every rock group. This structure is apparent as the boundary between the rocks of Gajah and Ijo volcano. This fact when associated with the map of the distribution of volcanic facies, geological map and geological sections will show the structure of northwest-southeast (NW-SE) that caused the collapse of Gajah volcano before the birth of Ijo volcano.

\subsection{Density of geological structures}

Based on the lineaments density variation map (Figure 5), it shows that the number of lineaments density is in the length range of $0-6 \mathrm{~km} / \mathrm{km}^{2}$. In the body of Gajah volcano formed several centers of density range of $5-6 \mathrm{~km} / \mathrm{km}^{2}$ and the spread is wide enough for density of $4-5 \mathrm{~km} / \mathrm{km}^{2}$ in the northwest. In the body of Ijo volcano, the density range of $4-5 \mathrm{~km} / \mathrm{km}^{2}$ and the distribution of density $5-6 \mathrm{~km} / \mathrm{km}^{2}$ formed in the middle of the volcanic body. At the body of Menoreh volcano, densities of $4-5 \mathrm{~km} / \mathrm{km}^{2}$ and $5-6 \mathrm{~km} / \mathrm{km}^{2}$ formed in the north and west of the volcano.

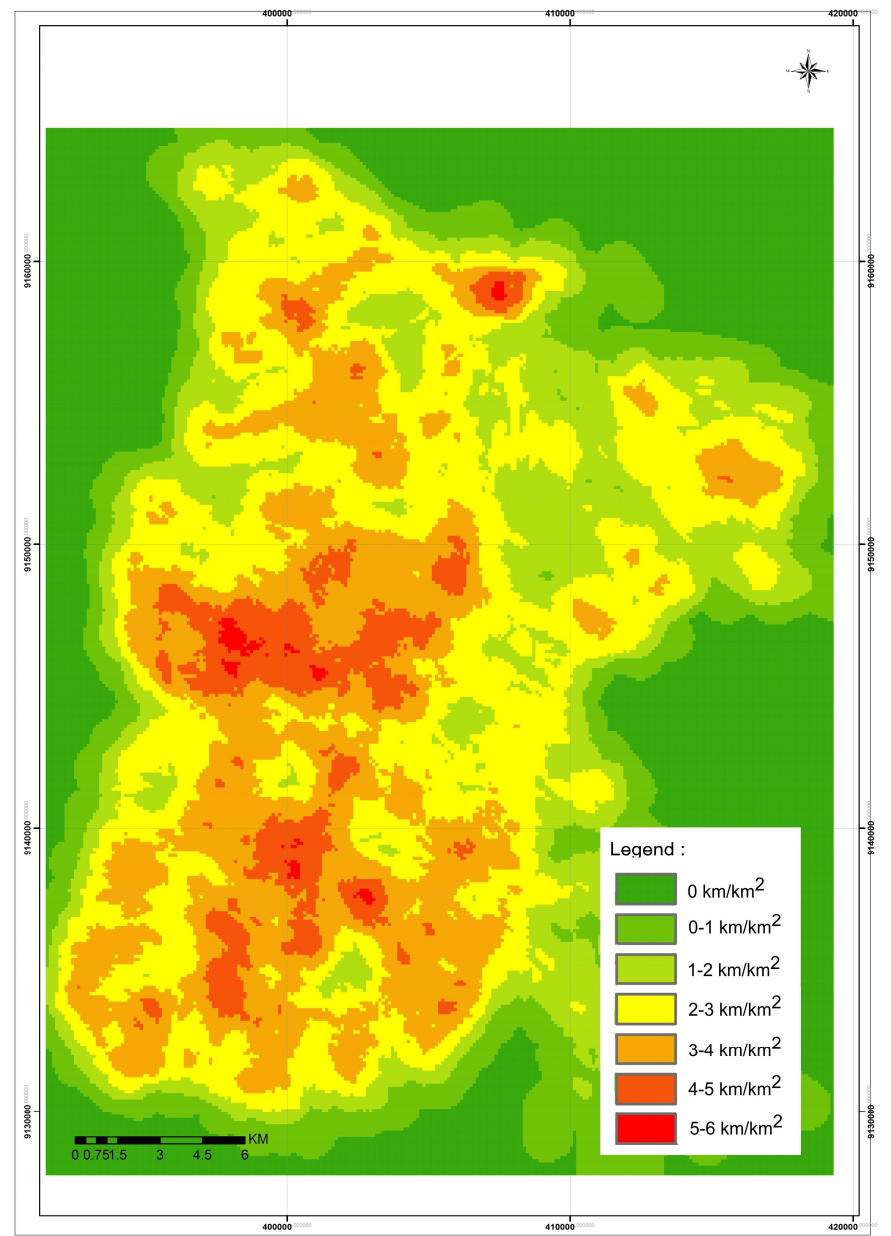

Fig. 5. Lineaments density variation map.

The density value of $0-1 \mathrm{~km} / \mathrm{km}^{2}$ is mainly developed in volcano-clastic rocks and sedimentary rocks on the eastern side of Kulon Progo Mountain. This area is composed of sandstone tuff, claystone, siltstone, conglomerate which is distal facies of Mount Gajah and Ijo. Limestone layered, thick marl, siltstone, calcareous sandstone which is a rock of Sentolo formation and also claystone, sandstone and marl of Nanggulan formation compose the eastern side of this Kulon Progo Mountain. The bending nature of these sediments in accommodating tectonic forces, further forms ductile deformation. The geological structure formed in this deformation is the fold, both anticlines and synclines. Less intensive joint and fault structures are formed in this rock group area.

The lineaments density of $1-2 \mathrm{~km} / \mathrm{km}^{2}$ mainly develops on the medial facies section of the Tertiary volcano. This area is mainly composed of tuffaceous breccia, andesite breccia, agglomerate, tuffaceous sandstone, conglomerate, siltstone and a thin layer of lava. The volcano-stratigraphy of rocks in this area shows a combination of ductile and brittle properties. Thus the fold structure still forms in this area, especially in claystone, conglomerate, clayey sandstone. The joint and fault structures also form on compact rocks such as tuffaceous sandstone and lava.

The lineaments density of $2-3 \mathrm{~km} / \mathrm{km}^{2}$ mainly develops in the proximal-medial part of the Tertiary volcanic body. This area is mainly composed of dominant andesite breccia, tuffaceous breccia, agglomerate, fragmental sandstone, clayey sandstone and a thin of lava. The volcanostratigraphy of rocks in this area shows a combination of 
ductile and brittle properties. Thus the fold structures are still formed in this area especially in the clayey sandstones. The joint and fault structures also form on compact rocks such as sandstones and lava.

Lineaments density of $3-4 \mathrm{~km} / \mathrm{km}^{2}$ mainly develops in the proximal facies of the three Tertiary volcano bodies. This area is mainly composed of dominant lava and volcanic breccia. The volcano-stratigraphy of rocks in this area indicates a brittle deformation. Thus the fold structure is not formed in this area. Intensive joint and fault structures are formed on compact rocks, such as in andesite/dacite intrusions, and andesite/basal lava.

The lineaments density between $4-6 \mathrm{~km} / \mathrm{km}^{2}$ develops in the middle of the three Tertiary volcanoes. This section is composed of basaltic lava, andesitic lava, andesite intrusive rock and dacite intrusive rock (Table 1). This area is part of the central-proximal facies of each Tertiary volcano body in the Kulon Progo Mountains. All of the rocks in facies are brittle in response to deformation due to tectonic forces that have occurred. Thus the rocks will be more likely to break if there is a tectonic force. Thus the joint and fault structures are very abundant in this section.

Lineaments mostly appear to lie on hard rock in the center of every Tertiary age volcanic body. This occurs in the proximal facies of Gajah, Ijo and Menoreh volcano. Andesite intrusion rock, dacite intrusion, andesite lava and basal lava in this section are brittle in response to tectonic forces that have occurred. While the part of the volcanoclastic rock that is formed away from the volcanic center, produces more ductile sediments in response to the tectonic forces that have occurred. Then, these rocks produce more folds and fewer joints and faults.

\section{Conclusion}

There are several conclusions resulting from this research:

1. Kulon Progo Mountain Area is composed of Tertiary volcanic rocks and Tertiary sedimentary rock formations. Tertiary volcanic rock consists of Gajah, Ijo and Menoreh volcano; which form the central, proximal, medial and distal facies of volcanic rock associations.

2. Central and proximal facies volcanic rocks have higher lineaments density than the medial and distal facies and sedimentary rock formations.

3. The central and proximal rocks facies composed of intrusive and lava rocks resulting brittle deformation, which produces joints and faults.

4. As the oldest volcanic rocks that have recorded all deformations, the central and proximal facies of Gajah volcano have a highest geological lineaments density than the central and proximal facies of other two Tertiary volcanoes. The older the volcanic rocks and the more to the center will be more deformed so that more lineaments will be produced.

The distal facies and sedimentary rock formations are ductile, thus forming a fold (syncline and anticline) in response to tectonic stresses
Table 1. Relation of lineaments density with rock types.

\begin{tabular}{|c|c|c|c|c|}
\hline No & $\begin{array}{c}\text { Lineament } \\
\text { Density } \\
\left(\mathrm{km} / \mathbf{k m}^{2}\right)\end{array}$ & Rock Types & $\begin{array}{c}\text { Volcanic } \\
\text { Facies/ } \\
\text { Formation }\end{array}$ & $\begin{array}{c}\text { Deformation } \\
\text { Result }\end{array}$ \\
\hline \multirow[b]{2}{*}{1} & \multirow[b]{2}{*}{$0-1$} & $\begin{array}{l}\text { Tuffaceous } \\
\text { sandstone, } \\
\text { claystone, } \\
\text { siltstone, } \\
\text { conglomerate. }\end{array}$ & Distal facies & $\begin{array}{l}\text { Ductile } \\
\text { deformation, } \\
\text { produces more } \\
\text { folding }\end{array}$ \\
\hline & & $\begin{array}{l}\text { Bedded } \\
\text { limestone, } \\
\text { thick marl, } \\
\text { siltstone, } \\
\text { calcareous } \\
\text { sandstone. }\end{array}$ & $\begin{array}{l}\text { Sentolo } \\
\text { Formation } \\
\text { (above distal } \\
\text { facies) }\end{array}$ & $\begin{array}{l}\text { Ductile } \\
\text { deformation, } \\
\text { produces more } \\
\text { folding }\end{array}$ \\
\hline 2 & $1-2$ & $\begin{array}{l}\text { Tuffaceous } \\
\text { Breccia, } \\
\text { andesite } \\
\text { breccia, } \\
\text { agglomerate, } \\
\text { tuffaceous } \\
\text { sandstone, } \\
\text { conglomerate, } \\
\text { siltstone. }\end{array}$ & Medial facies & $\begin{array}{l}\text { Ductile and } \\
\text { brittle } \\
\text { deformation }\end{array}$ \\
\hline 3 & $2-3$ & $\begin{array}{l}\text { Mainly } \\
\text { andesite } \\
\text { breccia, } \\
\text { tuffaceous } \\
\text { breccia, } \\
\text { agglomerate, } \\
\text { fragmental } \\
\text { sandstone, } \\
\text { clayey } \\
\text { sandstone and } \\
\text { a thin lava. }\end{array}$ & $\begin{array}{l}\text { Proximal and } \\
\text { Medial facies }\end{array}$ & $\begin{array}{l}\text { Ductile and } \\
\text { brittle } \\
\text { deformation }\end{array}$ \\
\hline \multirow[b]{2}{*}{4} & \multirow[b]{2}{*}{$3-4$} & $\begin{array}{l}\text { Mainly Lava } \\
\text { and volcanic } \\
\text { breccia }\end{array}$ & $\begin{array}{l}\text { Proximal } \\
\text { facies }\end{array}$ & $\begin{array}{l}\text { Brittle } \\
\text { deformation, } \\
\text { produces more } \\
\text { joint and fault }\end{array}$ \\
\hline & & $\begin{array}{l}\text { Reefal } \\
\text { limestone, } \\
\text { clastic } \\
\text { limestone and } \\
\text { thin marl. }\end{array}$ & $\begin{array}{l}\text { Jonggrangan } \\
\text { Formation } \\
\text { (above } \\
\text { medial } \\
\text { facies) }\end{array}$ & $\begin{array}{l}\text { Brittle } \\
\text { deformation or } \\
\text { effected by } \\
\text { basement } \\
\text { deformation }\end{array}$ \\
\hline 5 & $4-5$ & $\begin{array}{l}\text { Basaltic Lava, } \\
\text { andesitic lava, } \\
\text { andesite and } \\
\text { dacite } \\
\text { intrusion }\end{array}$ & $\begin{array}{l}\text { Central and } \\
\text { proximal } \\
\text { facies }\end{array}$ & $\begin{array}{l}\text { Brittle } \\
\text { deformation, } \\
\text { produces more } \\
\text { joint and fault }\end{array}$ \\
\hline 6 & $5-6$ & $\begin{array}{l}\text { Basaltic Lava, } \\
\text { andesitic lava, } \\
\text { andesite and } \\
\text { dacite } \\
\text { intrusion }\end{array}$ & $\begin{array}{l}\text { Central and } \\
\text { proximal } \\
\text { facies }\end{array}$ & $\begin{array}{l}\text { Brittle } \\
\text { deformation, } \\
\text { produces more } \\
\text { joint and fault }\end{array}$ \\
\hline
\end{tabular}

The research paper can be completed with the help of various parties. The expression of gratitude to the Ministry of Higher Education, which has provided scholarships to fund the research. Acknowledgments also to Dr. Agung Setiyanto who has provided image DEM Kulon Progo and surrounding areas. Field discussion with Dr. Gayatri I.M., Dr. Didit H.B. and Yan R.F. is very helpful for writing this paper. 


\section{References}

1. Van Bemmelen, R.W. The Geology of Indonesia. Vol. IA, General Geology of Indonesia and Adjacent Archipelago, Government Printing Office, The Hague. (1949).

2. Suroso, Rodhi, A., and Sutanto. Usulan Penyesuaian Tata Nama Litostratigrafi Kulon Progo, Daerah Istimewa Yogyakarta. Kumpulan Makalah Pertemuan Ilmiah Tahunan XV Ikatan Ahli Geologi Indonesia, Volume 1, IAGI-Yogyakarta (1987).

3. Rahardjo, W., Sukandarrumidi and Rosidi, HMD. Peta Geologi Lembar Yogyakarta. Pusat Penelitian dan Pengembangan Geologi, Bandung (1995).

4. Rahardjo, W., Sukandarrumidi and Rosidi, HMD. Peta Geologi Lembar Yogyakarta. Pusat Survey GeologiBadan Geologi-Kementrian Energi dan Sumberdaya Mineral. (2012).

5. Bronto, S. Fasies Gunungapi dan Aplikasinya. Jurnal Geologi Indonesia, Vol. 1 No. 2. (2006).

6. Budiadi, E. The Role of Tectonism in Controlling Geomorphology in Kulon Progo Area, Yogyakarta, Proceedings PIT IAGI Semarang, The $38^{\text {th }}$ IAGI Annual Conventional and Exhibition. (2009).

7. Barianto, D.H., Kuncoro, P. and Watanabe, K. The Use of Foraminifera Fossils for Reconstructing the Yogyakarta Graben, Yogyakarta, Indonesia. Journal of South East Asian Applied Geology, May-August 2010, Vol 2(2), pp 138-143. (2010).

8. Sudradjat, A., Syafri, I., and Budiadi, E. The Geotectonic configuration of Kulon Progo Area, Yogyakarta. Proceeding PIT IAGI Lombok 2010, The $39^{\text {th }}$ IAGI Convention and Exhibition, Lombok (2010).

9. Harjanto, A. Vulkanostratigrafi di Daerah Kulon Progo and Sekitarnya, Daerah Istimewa Yogyakarta. Jurnal Ilmiah MTG, Vol. 4 No. 2, Yogyakarta (2011).

10. Wijono, S. and Haryoprasetyo, H. Pengaruh Alterasi Hidrotermal dalam Proses Pembentukan Tanah untuk Pembuatan Zonasi Kerentanan Gerakan Tanah di Daerah Purwosari-Kebonharjo, Kecamatan GirimulyoSamigaluh, abupaten Kulon Progo, Yogyakarta. Prosiding Seminar Nasional Ilmu Kebumian Ke-4, Teknik Geologi FT-UGM, UGM, Yogyakarta (2011).

11. Widagdo, A, Pramumijojo, S., Harijoko, A. and Setiawan, A. Preliminary Overview of the Character, Patterns and Styles of The Geologic Structure of Kulon Progo Mountains Area and Its Potential as a Source of The Geological Structural Damage. Proceedings International Conference Jogja Earthquake in Reflection, Universitas Pembangunan Nasional, Yogyakarta (2016).

12. Widagdo, A, Pramumijojo, S., Harijoko, A. and Setiawan, A. Type, Pattern and Force Direction of the Geological Structure At Kulonprogo Area-YogyakartaIndonesia. The $6^{\text {th }}$ International Annual Engineering Seminar (InAES), Yogyakarta (2016).
13. Widagdo, A, Pramumijojo, S., Harijoko, A. and Setiawan, A. Kajian Pendahuluan Kontrol Struktur Geologi Terhadap Sebaran Batuan-Batuan di Daerah Pegunungan Kulon Progo-Yogyakarta. Proseiding Seminar Nasional Kebumian Ke-9, T. Geologi UGM, Yogyakarta (2016).

14. Widagdo, A, Pramumijojo, S. and Harijoko, ANU. Rekonstruksi Struktur Geologi Daerah Gunung Ijo di Pegunungan Kulon Progo-Yogyakarta Berdasarkan Sebaran Kekar dan Urat Kuarsa. Proseiding Seminar Nasional Kebumian Ke-10, T. Geologi UGM, Yogyakarta. (2017).

15. Hall, R., Clements, B., Smyth, H.R. and Cottam, M. A. A New Interpretation Of Java's Structure. Proceedings, Indonesian Petroleum Association, May, 2007. (2007).

16. Smyth, H., Hall, R., Hamilton, J. and Kinny, P., 2005. East Java: Cenozoic Basins, Volcanoes And Ancient Basement. Proceedings Indonesian Petroleum Association, Thirtieth Annual Convention and Exhibition.

17. Husein, S., and Nukman, M., 2015. Rekonstruksi Tektonik Mikrokontinen Pegunungan Selatan Jawa Timur: Sebuah Hipotesis berdasarkan Analisis Kemagnetan Purba. Proseding Seminar Nasional Kebumian Ke-8, FT-UGM, Yogyakarta.

18. Syafri, I., Budiadi, E. and Sudrajad, A., 2013. Geotectonic Configuration of Kulon Progo Area, Yogyakarta. Indonesian Journal of Geology, Vol. 8 No. 4.

19. Barianto, D.H., Abboud, E. and Setijadji, L.D., 2009. Structural Analysis using Landsat TM, Gravity Data, and Paleontological Data from Tertiary Rocks in Yogyakarta, Indonesia. Memoirs of the Faculty of Engineering, Kyushu University, Vol.69, No.2.

20. Soeria-Atmadja,R., Maury, R.C., Bellon, H., Pringgopawir, H., Polves, M., and Priadi, B. Tertiary Magmatic Belts In Java, Journal of Southeast Asian Earth Sciences. Vol 9, No.1. (1994).

21. Akmaluddin, Setijadji, D.L., Watanabe, K., and Itaya, T. New Interpretation on Magmatic Belts Evolution During the Neogene-Quarternary Periods as Revealed from Newly Collected K-Ar Ages from Central-East Java, Indonesia. Proceedings Joint Convention Surabaya-HAGI-IAGI-PERHAPI, The $30^{\text {th }}$ HAGI, The $34^{\text {th }}$ IAGI, and The $14^{\text {th }}$ PERHAPI Annual Conference and Exhibition, Surabaya. (2005).

22. Bronto, S. Geologi Gunung Api Purba. Publikasi Khusus, Badan Geologi, Kementrian Energi dan Sumberdaya Mineral, Bandung. (2010).

23. Bogie,I. and Mckenzie, K.M., 1998. The Aplication Of Volcanic Facies Models To An Andesitic Stratovolcano Hosted Geothermal System At Wayang Windu, Java, Indonesia. Proceedings $20^{\text {th }} \mathrm{NZ}$ Geothermal Workshop

24. Sabins, F.F., Remote Sensing Principles and Interpretation, $3^{\text {rd }}$ edition, New York, 93 